\title{
Innovation and Reflection on Peter Calthorpe's New Urbanism
}

\author{
Lei Yan ${ }^{1, a}$, Weiran Zhou ${ }^{2, b}$ \\ ${ }^{1}$ School of Architecture, Tsinghua University, Beijing, 100000, China \\ ${ }^{2}$ Dept. of Application and Research Institution of Engineering Technology, LEU, \\ Chongqing, 400041, China \\ ayanlei100@sohu.com, bweiran100@126.com
}

\begin{abstract}
Keywords: New Urbanism; Peter Calthorpe; transit-oriented development; low carbon cities; China Abstract. New Urbanism is a planning and design approach focused on human scale, diversity and conversation. Based on the introduction of New Urbanism and review Peter Calthorpe's famous books, this paper presents the innovations of Peter Calthorpe's New Urbanism covering from pedestrian pocket to transit-oriented development, from neighborhood to regional city and from sustainable community to low carbon cities, and considers Peter Calthorpe's multidisciplinary theory system and holistic perspectives that define the recent history of urban design in its most vital and prescient manifestations. Utilizing the empirical analysis of China's new town schemes guided by Calthorpe, this paper seeks to unpack the emergence, implementation, impact assessment and refinement of New Urbanism in China's new town and low carbon cities. Theoretically, multi-interest-oriented development, reforming public policy and completing market mechanism as well as controlling time and order of development are suggested to keep new town sustainable development. Meanwhile, from simple urbanism to green New Urbanism, it is re-positioned as a localized and politicized response to urban smart growth that needs indispensable support from transit-oriented development, mature public policies and eco-technology.
\end{abstract}

\section{Introduction}

In the last three decades, China's urban has undergoes rapid growth. Urbanization rate climbed from $17.92 \%$ in 1978 to $54.7 \%$ in 2015, which means 13 million people pouring into cities every year and China transforming into an urban-style society. To accommodate the growing urban population, urban construction area has increased by $7 \%$ per year in the last ten years. Urban boundary expansion means that natural open space and agricultural fields are disappearing and commute distances are increasing. Also, due to economy boom and improved quality of life, private automobile ownership has surpassed 100 million in 2014 and still surges at a rate of almost 20\% per year. This situation has been greatly changed urban travel modes and led to environmental degradation as well as enormous consumption of fossil fuels.

Therefore, as the largest developing county, phenomenal urbanization and mobilization result in China's total carbon emission making up 30\% of global total. Severe environment and energy issues imperatively demand China to reorient development mode. This situated complexity is similar with American in the 1950s. However, the American dream, which was characterized by high consumption and low density suburban sprawl, had been proved too extensive to suitable for China, and therefore China has to explore an effective path to coordinate development and conservation.

New Urbanism founded in USA and now prevailing around the world is a new paradigm for urban smart growth alternative to low density sprawl. As the most notable co-founder of Congress of New Urbanism (CNU) and an internationally recognized leader in green building, Peter Calthorpe continuously focuses on transit-oriented development (TOD), and conservation. In the last decades, Calthorpe has increasingly directed his attention to China and guided serials of low carbon cities schemes aided by the Energy Foundation. According to the elaborating of the Calthorpe's theory and the analysis of his practices, green urbanism based on TOD, mature public policies and eco-technology contribute to smart growth in China, although still subject to verification. 


\section{History of Urbanism and New Urbanism in USA}

In 1950s, America faced a complicated situation. The prevailing idea of massive production with massive consumption induced economy prosperity, baby boom and veteran resettlement after WII triggered skyrocketing housing demand. Meanwhile, ongoing racial tensions and economic inequality caused "white flight" and marked the beginning of the decline of the inner city. Under the pull force of demands and push force of movements, the Federal-Aid Highway Act and Housing Act enacted by federal government of USA further contributed to the forthcoming of the suburb sprawl era.

By the 1970s, the famous book of Silent Spring and the Limit to Growth: a report for the Club of Rome's project triggered the reflection of environments issues. At the same time, the oil crisis alarmed cities extensive growth. Both dilemmas of environmental issues and extensive growth compelled America to reflect on the low density sprawl mode which resulted in natural space destruction, habitat and inner city decline, residential segregation, and occupation and education inequality.

In the late 1980s, a multidisciplinary team of architectures, urban designers, planners, explores and engineers came together to tackle the challenges of urban illness and in 1993 they coalesced to create the Congress of New Urbanism. As a typical pragmatism, the CNU insists that urban physical space is the basis to resolve urban issues but not almighty, and considers that implementing multi-goals include the end of the suburb sprawl with existing urban center revitalization, besides the city legacy restoring and natural environments conservation. Peter Calthorpe, Andres Duany Elizabeth, Plater-Zyberk are the core cofounders of CNU, notably for the principles of tradition-neighborhood development and transit-oriented development.

Far from being confined to one organization, over the next three decades, New Urbanism theory frames and technology routes innovated with the times, and the debating topics range from neotradition, meaningful place, land-use and transit system to eco-environment, social and economy policies. Therefore, scores of scholars and developers, government officials from around the world focus on CNU continuously and closely.

\section{Innovation of Peter Calthorpe's New Urbanism}

Calthorpe's distinguishes himself through multi-career identities covering architect, urban designer and planner beyond his role as notable cofounder and the first board president of CUN. According to this multidisciplinary characteristic, Calthorpe's study and practice scopes divert from early passive solar architecture design, sustainable community design, to low carbon cities planning. Although the design scales continuously enlarge, the focus is always on conservation and sustainability. His affluent achievements in theory and practice promote the evolution of New Urbanism. Just as Metropolis Magazine claims "The titles of Peter Calthorpe's books define the recent history of urban design in its most vital and prescient manifestations". [1-3]

From Pedestrian Pocket to TOD. Pedestrian pocket, as described in Pedestrian Pocket Book [4], is a design strategy primarily for suburb renewal, comprising a simple space cluster of housing, retail and offices within 4-5 minutes walking distance around a transit system, ranging in size from 40 to 160 acres (Kelbaugh, 1989; Calthorpe, 1990). Later then in The Next American Metropolis (Calthorpe,1993), Calthorpe evaluated and matured the pedestrian pocket idea into TOD, which was distinctly characterized as supporting regional transit, mixed land use, quality open space and walk able street network.

From Neighborhood to Regional City. In The Regional City: Planning for the End of Sprawl [5], Calthorpe's comprehensive perspective ranging in scale from neighborhood, community, town, metropolis and regional city contributed to conceive the idea" regional city design is neighborhood design". This viewpoint argues that regional scale design integrates inner city revitalization with suburban renewal. Calthorpe recommends human scale, diversity and conversation as physical form design principles rather than standardized production and mechanism efficiency. 
From Sustainable Community to Low Carbon Cities. In sustainable community (Calthorpe, 1986) [6], Calthorpe redefined sustainable as the new strategy for human settlement development and explored more eco-technologies. Two decades later at a critical juncture of climate changing, Calthorpe provided four scenario planning for Vision California [7], comparatively analyzed four modes - trend sprawl, green sprawl, simple urbanism and green urbanism related to such indexes: land computation, housing mixed, infrastructure cost per household, carbon emissions and air pollutions, and concluded that green urbanism designed for a sustainable future was an inevitable also economic path.

\section{Characteristics and Effects of Calthorpe's New Urbanism}

Characteristics. As the most critical strategies of CNU, TND and TOD have striking similarity in preference to human-scale space, mixed function and meaningful place, while differences still exist. Differing from TND which attempts to recovery the legacy of American traditional neighborhood and also has been roundly criticized as nostalgic and middle-class amenity [8], TOD prefers to advocate affordable housing and convenient public transportation. As Calthorpe's New Urbanism theory matures, his study scales range from building, community to regional city, study elements include land-use, mass transit also eco-technology, study scopes vary from urban design to public policy-making and project practice, all aiming to implement real interdisciplinary and holistic thinking.

Effects. To date, Calthorpe has authored more than six seminal books, conceived and refined his classic design strategy-transit oriented development-which is now considered as a new paradigm for urban growth to alternate traditional sprawl. As a globally-recognized designer, Calthorpe's projects involve urban revitalization, community design, public planning and regional planning. Meanwhile, he integrates quantitative analysis with model software exploitation to continuously optimize design tactics and goals. In addition, Calthorpe's academic and practice fruits contribute to laws in many cities and states. For example, LUTRAQ planning in Portland city improved Oregon regional planning and urban growth boundary legislation [9], as well as Vision California Planning led to state's climate change legislation [10].

\section{Calthorpe's Practices in China and Related Reflections}

Typical Case Study. Since 2003, Calthorpe's association enters into China behalf of his private corporation and the National Energy Commission(NEC), to collaborate on Chinese low carbon cities planning - notably Chenggong, Kuming and Yuelai, Chongqing characterized by TOD which are elaborately introduced in his new book: Transit oriented development in China [11]. Specifically, in accordance with the local nature, economic and social advantages, convenient transit and slow transportation, compact land-use and mixed function, high quality open space on waterfronts and green land constitutes basic design principles for regional plan and urban development. Undoubtedly, in the last decade, TOD and low carbon cities have become prevailing topics around China's metropolises.

The new town of Chenggong, Kunming is nationally known as a pilot project for low carbon cities and for its New Urbanism design style guided by Calthorpe, but is also criticized as "ghost town" in the media [12]. Related queries focus on two aspects: the inconvenient of commercial facility and public transit result in push force deficiency; unbalanced work-live and absent employment lead to pull force lack. Consequently, scores of vacant buildings and barren civic life triggered above mentioned criticism: the ghost town is produced by New Urbanism.

Objectively speaking, Calthorpe was invited to guide Chenggong new town central district plan optimization aided by the Energy Foundation \& China Sustainable Cities Program in 2010, already five years after prime plan and construction. Therefore, it is not sensible to criticize TOD triggered the dilemmas in new town growth. 


\section{Calthorpe's Criticism on Issues of New Town Construction and Related Discussion}

Criticism. Flawed policy. Since there is no property tax in China, urban development financial expenditure mostly rely on local government's land fiscal which is prone to disorder estate exploitation and bubble with flooding the market with land. In addition, Chinese addicting in estate investment results in buy-now housing purchase and high vacancy level. [13]

Pursuit of utilitarianisms. In China, powerful government has absolute control over how new towns develop. Consequently, the capability of the local governance management largely determines the quality of urban development. Unfortunately, the defects of the prevailing assessment mechanisms of government performance inevitably result in the extreme pursuit of so-called "heroism planning", which eventually devolves into utilitarian achievements based on embezzling public resources, exaggerating urban scale and repelling classic life style.

Discussion. Diverting government controlled development to multi-interest-oriented development. Government-controlled development appears the superiority in conceiving imposing goals and rapid speed construction, but it is unstable and unsustainable. Particularly, complete government mediation and fiscal subsidies sees little success in supporting commercial facility and infrastructure operation, yet produce large government fiscal burden. Therefore, we suggest from three levels to develop sustainable and healthy new town. Foremost, from operation mechanism level, local government authorizes assigned development corporation with certain government properties to operate secondary development of land market aiming to relieve government investment risk. Secondly, for financing, local government is advised to adopt public-private-partnership development and built-operation-transit mechanism in infrastructure construction to reduce public fiscal budget. From governance levels, local government should promote non governmental organization and public to participate in community and government affairs to remedy the defects of up-bottom management.

Reforming public policy and completing market mechanism. It has been two decades since reforming the tax system back in 1994, which contribute to enhance state macroscopic controlling ability to deduce regional disparity. On the other hand, the deficiency of present tax system incentivizes local land fiscal, which leads to government rent-seeking activity spread and undermine the fundamental role of the market in the allocation of resources. It is time to restart financial and taxation reform, particularly on property investment and land premium tax policy modulation.

Controlling the time and order of development. Compared with cities of $19^{\text {th }}$ century which were relatively static and elegant with slow growth process, cities after industrial revolution take on explosive growth and disorder. Therefore we consider time as a vital dimension to evaluate urban development. In other words, urban growth is a long term process whether under natural force or mechanical force, and otherwise civic life quality will be the victim.

\section{Calthorpe's Strategies on Low Carbon Cities Planning and Related Effects}

Strategies. Presently China's urbanization and mobilization rate critically challenge the sustainable development of environment and energy resources. Under this imperative situation, Calthorpe provides serials adaptive design strategies for rapid growth China expressed in a manual of Land-use and Transportation for Low Carbon Cities.

Providing specific urban design principles [14]. In accordance with the specific characteristics of China, Calthorpe conceived eight urban design principles highly related to land-use and transportation organization aiming to explore smart alternatives for China's next generation of growth.

Strongly advocating small block design. In Calthorpe's opinion, the super blocks with single function prevailing in present China cities directly cause woke-live imbalance, transit congestion, and high social and environmental costs. By Comparison, small block ranging in size from 1 to 1.5ha contributes to generate abundant social capital, more frontage retail and public service space. In addition, his urban design criteria of small block highlight land-use compatibility and high level 
development intensity.

Recommending city grids. Dense street networks design corresponding to small blocks build city grids. As a new paradigm, it is conducive to balance multiple demands among private auto cars, mass transit, cycling and foot traffic aiming to shift cities from car-oriented to human-oriented. City grids quantitative indexes include such specific contents: road redline limits to $40 \mathrm{~m}$, otherwise one-way couplets will be introduced; supplementing auto-free path and branch way to encourage no-motorize travel; intercross interval dropping to $100-200 \mathrm{~m}$ from prime $500-800 \mathrm{~m}$ to plan a minimum of 50 intersections per square kilometer.

Related Effects. Promoting the completeness and systematization of low carbon cities construction. Instead of the biased recognition of low carbon cities construction meaning sets of technology schemes for specific issues in China, Calthorpe argues that low carbon cities planning depends on the integration and innovation of land-use plan, policy-making and green technology rather than only one certain plan or technology. Therefore, the situation of China's low carbon cities has a long way to go beyond laudable achievements.

Impetus for precise urban design. Now, urban design comes back to academic status to guide urban physical environment and context heritage. Consequently, the introductions of guidelines for low carbon cities help China's designers to recognize the essentiality of urban design and further to confirm the regulatory status of urban design between general planning to detailed planning.

Deepening quantitative and qualitative analysis. China's low carbon cities construction is still in demonstration phrase, whether small-block-oriented development adapts market regularity, whether one-way-couplets raises traffic efficiency as well as drops carbon emission, whether slow traffic system affects trip modes, whether a mix of income levels and age groups cultivates community social networks or not deserve further research and assessment. Therefore both obsessively relying on single development mode and rushing headlong into mass construction deserve calm rethinking.

\section{Summary}

Retrospection the innovation of Peter Calthorpe's design theory framework, three principles are fundamental: human scale, diversity and conservation. Walkable street and neighborhood are his design foundation and emphasis. The multidisciplinary and holistic study perspectives distinguish Calthorpe from his peers. Currently, Calthorpe's principles and practices for China's next generation of growth mainly focus on new town or district development aiming to balance urban growth and environmental conservation. In reality, we also realize that above mentioned theories and strategy are largely implemented in the reclaiming of brown fields and grey fields of USA, which is a more meaningful topic for the present China transiting from incremental planning to inventory planning.

\section{Refrences}

[1]https://www.cnu.org

[2]http://www.calthorpe.com

[3] Martin C. Pedersen, Q\&A:Peter Calthorpe, Point of View[J], Metropolis, July ,2013

[4]Kelbaugh, Doug et al, The Pedestrian Pocket Book [M]. Princeton, N.J: Princeton Architectural Press. 1989.

[5]Peter Calthorpe \& William Fulton, The Regional City: Planning for the End of Sprawl [M], Island Press, 2001

[6] Sim Van der Ryn \& Peter Calthorpe, Sustainable Communities: A New Design Synthesis for Cities [M], Suburbs and Towns, San Francisco: Sierra Club Books, 1986.

[7] Peter Calthorpe, Urbanism in the Age of Climate Change [M], Island Press, 2011

[8] Kennth Kolson, Big Plans: The Allure and Folly of Urban Design [M], the Johns Hopkins University Press, Baltimore, Maryland, 2003

[9] Peter Calthorpe \& William Fulton, The Regional City: Planning for the End of Sprawl[M], Island Press, 2001 
[10]Peter Calthorpe, The Next American Metropolis: Ecology, Community, and the American Dream [M], N.J: Princeton Arichetectural Press, Inc, 1993

[11]Peter Calthorpe, Baojun Yang and Quan Zhang, Transit Oriented Development in China - A Manual of Land-use and Transportation for Low Carbon Cities [M], Beijing: China Architecture and Building Press, 2014.

[12] http://finance.sina.com.cn/china/dfjj/20140618/072019444981.shtml

[13]Peter Calthorpe, Urban Destruction: a Path to Superpower Status [J], The Cities issue, Sepetember-Qctober, 2012:68-71

[14]China Design Manual Pamphlet [EB/OL], [2015-12-20], http://www.calthorpe.com 